\title{
Unique RNA species developed during a shock avoidance task'
}

BARRY MACHLUS AND JOHN GAITO, DEPARTMENT OF PSYCHOLOGY, YORK UNIVERSITY, Toronto, Canada

A DNA-RNA successive competition experiment in which DNA is hybridized first with brain RNA from rats subjected to forced motor activity and then with brain RNA from shock avoidance trained rats suggests that unique RNA species are synthesized during this latter task.

Some individuals have claimed that unique RNA species are synthesized in the brain of behaving organisms. (See the review by Gaito, 1966.) One means of determining if unique species occur during behavior is by DNA-RNA successive competition hybridization procedures. These procedures involve splitting double stranded DNA into single strands, trapping these strands on a nitrocellulose membrane, and hybridizing the DNA first with brain RNA from control rats and then with brain RNA (labelled with $\mathrm{H}^{3}$ ) from behaving rats. Results of previous experiments in this laboratory using DNA-RNA successive competition hybridization procedures suggested that unique RNA species were synthesized during a shock avoidance task (Machlus \& Gaito, 1968). However, these RNA species may have been synthesized as a result of the electric shock, sensory stimulation, or motor activity involved in the shock avoidance task, rather than from the learning process. The present experiments were conducted to determine if the unique species synthesized during the shock avoidance task were a result of motor activity.

Methods

In these experiments DNA was extracted from brain tissue using four cold phenol steps, the last one preceded by RNase treatment. RNA was obtained by repeated phenol treatments, one of which was at $60 \mathrm{deg} C$ so as to separate rapidly labelled messenger RNA. The hybridization procedure was that of Gillespie \& Speigelman (1965).

In Experiment 1, eight pairs of littermate male albino rats (Wistar strain; age 110 days; weight about $320 \mathrm{~g}$ ) were used. All experimental rats were injected intracranially with $200 \mu \mathrm{c}$ of orotic acid $5-\mathrm{H}^{3}$ (specific activity, $13.8 \mathrm{c} / \mathrm{mM}$ ) in physiological saline. Orotic acid is a precursor of uridylic acid for RNA. Control animals were injected with unlabelled orotic acid. Sixty min later each experimental animal was placed in a one way active shock avoidance apparatus. After $15 \mathrm{~min}$ of adaptation in the shock chamber of the apparatus, the experimental animal (learning-L) was given 15 trials in 15 min and sacrificed by immersion in liquid nitrogen for $10 \mathrm{sec}$. Each control rat (motor activity-MA) was placed on a stationary treadmill $60 \mathrm{~min}$ after being injected. Fifteen min later the belt began to revolve at approximately 4 rpm. The rat was sacrificed $15 \mathrm{~min}$ later. All eight learning animals showed 10 or more avoidance responses in the 15 trials (Mean, 10.9; Standard Deviation, 0.35).

The brain of each rat was removed and divided into two approximately equal halves by a vertical cut. Each portion consisted of a cerebral hemisphere and one half of the cerebellum and brain stem. DNA was extracted from one portion and RNA from the other.

With the two rats in each of the eight pairs, four hybrids were obtained as shown in Table 1a. Hybrid 3 was the crucial one. The dpm (above background) of the membranes of Hybrids 1, 3, and 4 were determined in a liquid scintillation spectrometer. The RNA in Hybrid 2 was eluted with $0.01 \mathrm{M}$ Tris buffer $(\mathrm{pH} 7.3)$ and determined by absorbancy readings in a spectro photometer. In each liybrid $50 \mu \mathrm{g}$ of RNA was hybridized with $50 \mu \mathrm{g}$ of DNA; the dpm in $50 \mu \mathrm{g}$ of RNA was used to determine the $\mu \mathrm{g}$ of RNA complexed with the $50 \mu \mathrm{g}$ of DNA (Machlus \& (Gaito, 1968).

Results and Discussion

Table 1 a indicates for each hybrid condition the mean $\mu \mathrm{g}$ RN $\Lambda$ hybridized and the expected mean $\mu \mathrm{g}$ RN $\Lambda$ hybridized. This latter value (1.10) was obtained previously (Machlus \& Gaito, 1968). In each of the eight pairs, the $\mu \mathrm{g}$ RNA hybridized in the crucial double hybridized DNA (Hybrid 3) was greater than zero. Such results are significant at $\mathrm{p}<.01$ with a Binomial Test. Likewise in each pair, the values in Hybrids 1 and 4 were approximately the same, and both values were greater than that for the motor activity rats (Hybrid 2). Binomial Tests indicated that Hybrids 1 and 2 and 2 and 4 were different $(p<.01) ;$ Hybrids 1 and 4 were not significantly different.

These results are consistent with the previous ones and suggest that during the last $15 \mathrm{~min}$ of the $90 \mathrm{~min}$ period for incorporation of the labelled precursor, additional species of RNA appeared in the brain of the shock avoidance trained animals (Hybrid 3). This conclusion is corroborated by the differences between Hybrid 1 and 2 and Hybrid 2 and 4. The difference between the two in each case is approximately as great as the $\mu \mathrm{g}$ RNA hybridized in 3 .

To check on possible artifacts, Experiment 2 was performed with two pairs of littermate rats. This check consisted of reversing the entire procedure by injecting the motor activity animal with the labelled precursor and the learning animal with the nonlabelled material. Two crucial Hybrids were 3 and 4 (Table $1 \mathrm{~b}$ ). If the results in Hybrid 3 in Experiment 1 were an artifact, one would expect that label would be detected in both hybrids. The $\mathrm{dpm}$ in each case was not above background for two samples in each of the two replications for both hybrids.

Two other hybrids determined the amount of RNA hybridized during single hybridization for the motor activity animals (Hybrid 1) and for the learning animals (Hybrid 2). The mean value of Hybrid 1 (1.19) is 0.21 greater than the value obtained in Experiment 1 (0.98). Likewise, the mean value in Hybrid 2 (1.25) is 0.31 less than that obtained in the comparable hybrid in Experiment 1 (1.56). This discrepancy is based on the different methods of estimating amounts of RNA in Hybrids 1 and 2. In Experiment 1 two samples of Hybrid 1 were obtained for each replication. The $\mu \mathrm{g}$ RNA for one was determined via liquid scintillation spectrometry; the RNA from the second one was eluted and determined by absorbance readings. The absorbance readings indicate lower RNA values in all cases (mean from absorbance readings, 1.33; mean difference, 0.23 ).

These discrepancies indicate that the $\mathrm{dpm}$ from liquid scintillation spectrometry can not be used in an absolute manner. To consider the $\mathrm{dpm}$ as absolute values requires that the $\mathrm{H}^{3}$ be incorporated uniformly throughout the various RNA species. However, it appears that there are different specific activities for various RNA species, which is what one would expect.

Table 1

Hybridization Procedures and Mean Micrograms of RNA Hybridized

\begin{tabular}{|c|c|c|c|}
\hline Hybrid & Mean & SD & Expected Mear \\
\hline \multicolumn{4}{|l|}{ (a) Experiment 1} \\
\hline 1. $\operatorname{DNA}_{\mathrm{L}}-\mathrm{RNA}_{\mathbf{L}}$ & 1.56 & 0.05 & 1.10 \\
\hline 2. DNA $_{M A}-$ RNA $_{M A}$ & 0.98 & 0.17 & 1.10 \\
\hline 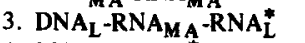 & 0.63 & 0.14 & 0.00 \\
\hline 4. $\mathrm{DNA}_{\mathrm{MA}}-\mathrm{RNA}_{\mathrm{L}}^{*}-\mathrm{RNA} \mathrm{MA}_{\mathrm{A}}$ & 1.43 & 0.20 & 1.10 \\
\hline \multicolumn{4}{|l|}{ (b) Experiment 2} \\
\hline 1. $D_{N A_{M A}}-R_{N A}^{*}$ & 1.19 & 0.00 & 1.10 \\
\hline 2. $\mathrm{DNA}_{\mathrm{L}}-\mathrm{RNA}_{\mathrm{L}}$ & 1.25 & 0.06 & 1.10 \\
\hline 3. $\mathrm{DNA}_{\mathrm{L}}-\mathrm{RNA}_{\mathrm{L}}-\mathrm{RNA}_{\mathrm{MA}}^{*}$ & $0.00^{+}$ & 0.00 & 0.00 \\
\hline 4. DNA $M_{M A}-R N A_{L}-R N A_{M A}^{*}$ & $0.00^{+}$ & 0.00 & 0.00 \\
\hline
\end{tabular}

*Asterisk indicates the presence of labclled precursor in RNA; SD is standard deviation.

+All samples were equal to or less than $3 \mathrm{dpm}$ abol'e background $(49 \mathrm{dpm})$ and thes were comsidered to have a lahe' of o $\mu \mathrm{g} R N^{\prime} A$. 
Such discrepancies do not vitiate the conclusions of Experiment 1. If the value in each Hybrid 2 sample is increased by 0.23 , the $\mu \mathrm{g}$ in Hybrids 1 and 4 are greater than those in Hybrid 2 in all cases. Likewise, in all cases the absorbance values for Hybrid 1 in Experiment 1 were greater than the absorbance values for Hybrid 2.

These results are consistent with those of the previous experiments and suggest the synthesis of unique brain RNA species during shock avoidance conditioning which are different than those synthesized in nonbehaving and in motor activity tasks. It appears that these species are not due to the motor activity involved. However, the motor activity was of a forced, continuous nature whereas the motor activity during the shock avoidance training is of intermittent character. Further experiments are underway to evaluate this aspect and other possible contributors, mainly electric shock, to the synthesis of RNA during shock avoidance conditioning.

\section{REFERENCES}

GAITO, J. Molecular psychobiology. Springfield, Ill.: C. C. Thomas, 1966. GILLESPIE, D., \& SPIEGELMAN, S. A quantitative assay for DNA-RNA hybrids with DNA immobilized on a membrane. J. mol. Biol., 1965, 12, 829-842.

MACHLUS, B., \& GAITO, J. Detection of RNA species unique to a behavioral task. Psychon. Sci, 1968, 10, 253-254.

\section{NOTE}

1. This research was supported by Office of Naval Research Contract Nonr $4935(00)$ and Grant No. APA-122 from the National Research Council of Canada. 